DOI: https://doi.org/10.15407/uhj2020.02.187 UDC: $930.1(438+477)$
Mariia Mandryk-Melnychuk

Doctor of Historical Sciences (Dr. Hab. in History), Professor at Department of Social Medicine and Public Health,

Bukovinian State Medical University

(Chernivtsi, Ukraine), mandricescu@yahoo.com ORCID: http://orcid.org/0000-0001-5995-9003

Anatolii Kotsur

Doctor of Historical Sciences (Dr. Hab. in History), Professor at Department of Ethnology and Local History,

T.Shevchenko National University of Kyiv

(Kyiv, Ukraine), kotsurap@meta.ua

ORCID: http://orcid.org/0000-0002-7015-8052

Tamara Sharavara

Doctor of Historical Sciences (Dr. Hab. in History), Professor, Vice-Rector for Scientific and Pedagogical Work and Perspective Development,

Poltava State Agrarian Academy

(Poltava, Ukraine), 125125.tsh@gmail.com ORCID: http://orcid.org/0000-0002-6370-6663

\title{
Historical Interpretation of the Past: The Way of Mental Enslavement or Liberation?
}

\begin{abstract}
The purpose of this study is to find out the role of a professional researcher in historical interpretation of the past, to analyze projected threats that deal with speculation of historical facts, events, their arbitrary use, deliberate distortion of them for the formation of historical and social memory. The research methodology. The research is based on the principles of historicism, comprehensiveness, objectivity and systemacity. General scientific methods of analysis, synthesis, generalization, specialhistorical (retrospective, comparative, problem-chronological), as well as the method of interdisciplinary and polydisciplinary synthesis are used in the presentation of the material. The scientific novelty. The roles that a professional researcher of the past can play - from the propaganda of hostile ideas, selective interpretation of sources, speculation on a certain topic - to an impartial re-enactor, a competent expert are analyzed. It is proved that suppression or deliberate distortion of particular pages of history, or their excessive ideologization, which was actively practiced in the Soviet science, equates with political violence, the manipulation of the consciousness of entire communities and generations. The use of such approaches has always been destructive in nature for researchers, who fulfilled the functions unusual to them, and for society, which, because of ignorance of its own past, is losing the vision of its future now. Conclusions. Consequently, manipulations with the interpretation of the past - different understanding of the same milestone events, excessive politicization of them, promotion of the enemy's image, deliberate emphasis on human emotions, ideological layers associated with a particular page of people's life - have an irreversible impact on the formation of social memory of Ukrainians. These factors contribute to deepening the processes of disintegration of society and indirectly strike at the foundations of nationhood.
\end{abstract}

Keywords: historical memory, social memory, violence, manipulation, historical interpretation, historiography, mentality.

Manipulation involves the use of the system of ideological, spiritual and psychological influence on the consciousness in order to peddle certain ideas, images, values, a style of behaviour, the formation of "necessary" prism of reality perception. Moreover, it is aimed at rooting a new style of thinking in minds of at least several future generations. The example of this is the Soviet mentality - symbolics, holidays, traditions, educational system and the impact on young generation, the prism through which it is not enough 
to understand and interpret the past - all of these things have formed a new way of life that we are have been trying to eradicate for more than a quarter of a century by means of decommunization, deideologization, the review of key areas of scientific research, the correction of teaching history programs, the concepts of national-patriotic nature. In our opinion, all these measures are more decorative, cosmetic and can not radically change the state of things. The way of neglect, removal or erasing is fruitless, leads to nowhere, because it does not touch upon more fundamental processes that implanted in our subconsciousness. Thus, the "disease" is preserved instead of being treated and free of it.

Before talking about history as one of the most effective and most fruitful means of forming mentality - as a consolidating factor or as a new coordinate system that is essential for the establishment and entrenchment of power, it is necessary to analyze the content of such key definitions as "social memory", "historical memory", "collective memory", etc.

Taking into account some aspects of the formation of social memory, its relation with the historical understanding of the past, it can be said that it is a comprehensive notion, which includes historical memory. Social memory integrates the whole spectrum of events, a style of thinking, a lifestyle of the people, their ritual, emotional sufferings, mental states, and historical one, with the help of an arsenal of sources, which are operated by a specialist - archaeological, written ones, memoirs, allows you to recreate the true picture of the formation of the people's social experience. All the cataclysms of the past, the tragedies, the violence that was used against a separate nation, in particular Ukrainians, break down mentality, the way of development, the level of national self-awareness and self-identification, and, therefore, all of these things integrate into social memory.

A distinction is made between historical memory as a memory of specific historical events and social memory, which keeps a much wider range of phenomena of social nature: peculiarities of everyday life, ritual, mood, psychoemotional state of people, their feelings. Historical memory is considered as a set of historical messages, myths, especially with a negative content, oppression, tragic pages that are passed down through the generations.

Historical memory is a kind of collective memory. It is hardly homogeneous in its content, intensity and depth. One can talk about the social structure of historical memory, more precisely, the historical component of social memory. Historians act as its keepers, carriers, because they study professionally and interpret the past.

The definitions of "historical memory", "social memory", "collective memory" over the past decades have been of a great scientific interest. The interest is not only purely theoretical, but also due to the need to reconsider outdated stereotypes, ideologemes and mythologemas that have implanted in the minds of Ukrainians since the Soviet era. A post-totalitarian society can be developed and changed if it is well understood which coordinate system it is necessary to rely upon when members of the community are aware of what hindered development for a long time. However, without highlighting the key points in the historical past, further progress will be utopian. Thanks to proficient speculation around particular pages of history, periods, figures, there is a tendency for further dispersal of Ukrainian society. This situation reminds a patient who wants to be treated for a mental disorder associated with past experiences, but by means of forced fragmentary oblivion rather than deep self-reflection.

A lot of Western, Russian and national scientists paid their attention to the phenomenon of social memory, its forms of commemoration. First of all, this refers to the research by M.Halbwachs, A.Assman, Yu.Lotman, L.Starodubtseva ${ }^{1}$. Also the

${ }^{1}$ Хальбвакс M. Социальные рамки памяти / Пер. с фрр. - Москва, 2007. - 348 с.; Его же. Коллективная и историческая память // Неприкосновенный запас. - 2005. - №2/3 (40/41). - С.8-27; Ассман А. Длинная 
works of classics should be mentioned - by H.Bergson, the French idealist philosopher, the representative of intuitionism, and the sociological works by E.Durkheim, which gave impetus to the study of this range of problems. The problem of the formation of social memory, overcoming of the consequences of tragic pages of the past experienced by Ukrainians, during the last decade, has been vividly discussed by Ukrainian researchers. In particular, the researcher O.Stasiuk thinks that the causes of the genetic fear of Ukrainians are three Holodomors that the nation suffered from ${ }^{2}$. In her opinion, these tragedies are engraved on the genes of people, radically changing the society. The research by L.Zashkilniak, Ya.Kalakura, V.Marochko, V.Karlova, E.Podniakova-Kyrbiatieva, V.Bakirov ${ }^{3}$ is devoted to the problem of historical memory, ways of restoring it in the post-Soviet society.

The well-known Ukrainian scientist, historian L.Zashkilniak put a wide interpretation on the definition "historical memory" as the ability of the mind to keep the individual and collective experience of human communication, as well as to form it based on the idea of the people's past and the own place in this past ${ }^{4}$. This kind of memory is an integral component of social consciousness and is formed as a result of the intellectual activity of specific individuals, who are capable of creating and disseminating a certain social vision of life for some part of the community ${ }^{5}$. In this context L.Zashkilniak finds out what the relation is between historical memory and historiographical science, what part they play in the formation of historical consciousness. Historiography reproduces a picture of the past, and historical memory is produced on the basis of personal and social experience and feelings. For the latter, heroic figures, dates, places with which the community identifies itself are especially important. Frequently, historical memory contains a lot of stereotypes, myths, exaggerations.

For the first time, the term "collective memory" for scientific study was introduced by the French sociologist M.Halbwachs - one of the brightest representatives of E.Durkheim's school. In 1925, his work entitled "Social Borders of Memory" was published, in which he interpreted the definition as a peculiar set of knowledge, ideas, memories, experiences of the past, which are of great value for the past and future of the people. Within this context, the use of the term "re-enactment" is argued - according to M.Halbwachs, only in such a way it is possible to specify historical research, since historians are able to reproduce the past only approximately, it will approach the real variant as much as more written or oral testimonies and evidences will be available to them. "In order to

тень прошлого: Мемориальная культура и историческая политика / Пер. с нем. - Москва, 2014. - 323 с.; Лотлан М.Ю. Память в культурологическом освещении // Его же. Избранные статьи. - Таллин, 1992. - С.200202; Стародубцева Л.В. Память и забвение: Древо истории идей: Собрание текстов. - Х., 2000. - 686 с.; Eё же. Мнемозина и Лета: Память и забвение в истории культуры. - Х., 2003. - 696 с.

2 Стасюк O.O. Деформація традиційної культури українців в кінці 20-х - на початку 30-х рр. XX ст.: Авторефр. дис. ... канд. іст. наук. - К., 2007. - 17 с.

3 Зашкільняк Л. Історична пам'ять та історіографія як дослідницьке поле для інтелектуальної історії // Україна: культурна спадщина, національна свідомість, державність. - Вип.15. - К., 2006-2007. - С.88-862; Його ж. Небезпеки історичного мислення та соціальні функції історика у сучасному світі // Історик і влада. - К., 2016. - С.133-143; Калакура Я. «Синдром комунікації істориків і його живучість у пострадянській українській історіографії // Там само. - C.55-77; Марочко B.I. «Торгсини»: золота ціна життя українських селян // СхідноСвропейський монітор. - 2004. - №5. - С.14-15; Карлова В. Особливості відновлення історичної пам'яті українського народу у контексті аналізу досвіду постсоціалістичних країн // Демократичне врядування. Вип.1. - Л., 2008. - С.45-53; Познякова-Кирбятєва Е.Г. Концептуалізація поняття і явища соціальної пам'яті // Вісник Міжнародного слов'янського університету. - Т.XV. - Х., 2012. - №1/2. - С.15-21; Бакіров В.С. Історичні форми ціннісної свідомості // Вісник Харківського національного університету ім. В.Н.Каразіна. - Вип.12 (№511). - Х., 2001. - С.9-15; Вип.13 (№527). - С.9-13.

4 Зашкільняк Л. Історична пам'ять та історіографія як дослідницьке поле для інтелектуальної історії. - C.855.

5 Там само. - C.856. 
put ourselves in exactly the same state of mind, we need to remind at the same time, without exception, the influence which we were fallen under at that time from the inside and outside, just as it would have been necessary to raise all participants and witnesses

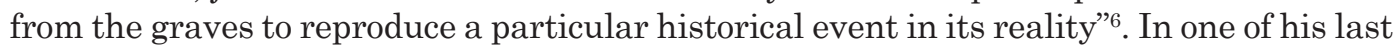
works, "Collective and Historical Memory", M.Halbwachs states that the man has two kinds of memory - individual and collective. He describes an individual one as personal, autobiographical, and collective one that is social. In the case of an individual kind of memory, memoirs are built around one person, all events are considered by the man through his own prism, but exactly as far as this past affects the person himself. The researcher characterizes it as more integral, continuous, such that, in many cases, can rest upon the collective. Collective memory is an idea of the person's past as a member of a certain group, community, nation, which in a specific way deal with this group. However, it is limited, because the man can not know everything from the past of the group - only according to oral information provided by others, partly own memories, as the term that a person has already lived permits, the memories of other members of the community. M.Halbwachs calls this memory borrowed, because we can not a priori know the history of our people from our own memories, only a small segment that coincides with our life, and all the rest can only be known through memories, memoirs, manuscripts, chronicles, documents, etc. M.Halbwachs states that there is a significant difference between vision of the past by adults and children - adults, first of all, reproduce economic concepts, phenomena, an aesthetic side of things, cyclical events, and children's memories are built around those places where they spent their best days, around their family, home environment, emotional experiences, relationships ${ }^{7}$.

So when we use memories of eyewitnesses, we must take into account this important peculiarity - many things may just be passed over and we can get a distorted picture of events. However, frames of social memory are expanding with age ${ }^{8}$ The author finds out how the disappearance or transformation of memory frames entails the disappearance or transformation of our memoirs. Halbwachs presents two hypotheses - the first one is the frame and the picture itself - they are made of different materials, substances, as well "the bed of the river, the banks of which limit the flow, but only are mirrored on its surface...". The second - the frame and the events are identical by nature: the events are memoirs, but the frame consists of memoirs. H.Bergson is a supporter of the first hypothesis, according to which human memory deals with two kinds of memory - the first - one memory keeps the facts that occurred only once, another - those that were repeated ${ }^{9}$.

Collective memory deals with the term "social time" - the external time, in relation to the time that a person experiences. In addition, we can "tie" different phases of life to events of national importance only "backdated", because every event in history will become a historical stage only later, but not immediately - a person already in adult life as if learning to enter the childhood in the history of the period. There is a peculiar picture of the events on which we focus profiles of our parents, relatives, friends, acquaintances. This process is similar to the restoration of fragments of a fresco that were not enough, events and details are interconnected so as to restore the original appearance of the fresco. When we want to imagine, let's say, the life in 1980s, our thoughts are immediately addressed to our parents, teachers, acquaintances. According to M.Halbwachs, it is better not to distinguish personal memory, which is not beyond our

\footnotetext{
${ }^{6}$ Хальбвакс M. Социальные рамки памяти. - С.125-126.

7 Там же. - C.121.

8 Там же. - C.135.

9 Там же.
} 
close group of family members and acquaintances, and historical one, which contains national events that we might not have known. There is a strange situation, because we seem to need to get out of one memory in order to fall under another - historical (national) one - but we have already lived in it. Individual memory is more specific, simpler, experienced. It is interesting that individual (autobiographical) memory is formed in a confined space of personality. When is an exit from this closed world? When a child moves from a sensory level of perception of realities to a conscious understanding of surrounding images and events, one can say that this personality thinks together with others, there is a distinction between personal and collective things. The first communication of a child on serious topics, the preview of news, reading newspapers, magazines will be steps to exit from the closed system in another completely unknown world. However, this will happen gradually, depending on widening of the circle of acquaintance, the difficulty level and quality of information that a child will receive.

We are approaching the main question of our study - the determination of the role of the historian in reproducing a holistic vision of the past, how in his hands history can turn into the way of consolidation, spiritual mobilization of the nation or in the way of enslavement through one-sidedness, falsification. By interpreting the pages that are important for the perception of the people interestedly, thereby historians and reserach institutions can indirectly cause a split in society.

The modern French historiographer F.Hartog has outlined several roles that the historian wants to play and avoids, and also found out quite how these roles have evolutionized since the nineteenth century, when the historian was considered as a mediator between the past and the present. Thus, the author clearly describes the types of roles and circumstances that somewhat complicate their fulfilment. Proceeding from the fact that memory should be understood as a concept that creates the very present, F.Hartog states that, due to his knowledge, the historian plays the role of an educator in the conditions of globalization of the world. In his opinion, there is one key contradiction - between the historian and time: time has a double dimension - as the chronological framework it examines and as the period to which it belongs. Thus, the historian is responsible for interpreting the past, but at the same time he must remain as sensitive as possible to the present. However, this process is not identical to the fixation and reproduction of current events as in the case with journalism. According to F.Hartog, a modern historian plays the role of a witness, because he provides the necessary facts and only in such a hypostasis he is involved in the work of various expert commissions. Can the historian compete in the operational efficiency of reproducing "live history" with journalists, modern YouTube channels, blogs, information portals that react on events instantly? To this list, we should add live participants, eyewitnesses of very recent periods of history, which can directly reproduce the events of the Holocaust, Holodomor, political repressions, etc., without the participation of the historian himself, F.Hartog believes that memoirs have become a part of political and social events and are actively involved in the creation of collective memory being presented in TV airtime, films. Despite the fact that professional historians did not immerse in the modern for them socio-political life, however, due to their appealing to the topics of the tragic pages of the twentieth century, there was an irreversible effect on the formation of priority research areas, the publication of scientific works, the appearance of television projects. Thus, in such a way, they not only actualized these historical problems, but formed the prism of their presentation and changed the perception of importance of their profession as an authoritative commentator ${ }^{10}$.

${ }^{10}$ Артог Ф. Какова роль историка во все более «презентистском» мире? [Електронний ресурс]: http://gefter.ru/archive/8000 
However, it is necessary to take into account a number of factors that substantially correct the role of a professional historian in the reproduction (deformation) of the past. In this regard, there is an interesting approach of the modern British social anthropologist P.Connerton - a prominent specialist in the field of memory research. In his work "How Societies Remember", which occupies one of the leading places in cultural (social) anthropology, he advanced the thesis that public consciousness, historical memory were the result of the intellectual work of individuals, who were able to outline the vision of society, the ways of its development. Speaking about the formation of historical memory, the researcher cites the names of the most significant historians - Th.Mommsen, L. von Ranke, F.K. von Savigny, B.G.Niebuhr, who were closely connected with the political reality of that time. This, according to P.Connerton, created a precedent for political bias, which led to a certain one-sidedness, the formalization of history. "Creation of stories-narratives, presented in a more or less informal aspect, appears as the main form of activity to characterize human actions. This is the peculiarity of common memory"11. Historical works (re-enactment) are somewhat desiccated versions of the past, because researchers of the past often collect information through interviews of eyewitnesses, witnesses of events, and they stress topics in questions themselves, use necessary intonation, push the respondent for a certain chronological order when presenting events ${ }^{12}$. In addition, this refers to people who had a real impact on the course of events, the fate and fortunes of others, the formation of an official opinion, then during the interview, they can deliberately "bleach"/"blacken" the past. Let's recall the memoirs of odious figures of the communist time that inspire nostalgia about the Soviet era and retouch many horrible pages. We deal with rewriting history. According to P.Connerton, memoirs which historians often use in their research arouse criticism as well. First of all, this is about memoirs of influential people, politicians, military men - people who "were in the very heart of the structure of the dominant institutions and could change the structure, influence it, pursuing their own goal"13.

This version of the presentation of the past does not coincide with oral history belonging to "subordinated groups"14. The details and events in the life stories of the members of these groups (ordinary citizens, but not those who were influential and may have concerned the formation of the certain worldview of other people - old communist leaders, ideologists, military commanders, leaders of movements) look on another note, they can intentionally miss many important facts to show themselves to advantage. In other words, history can become a means of manipulating the consciousness of the community subject to ideological bias of the researcher. As a result, we get a false artificially constructed "historical memory" instead of real memoirs of the past. This false "historical memory" is passed down through the generations, undergoing correction by media, political technologists, analysts. Teachers, scientists, priests, journalists, public activists, demagogues get involved in the process of mythologization of the past.

In the novel "1984", the famous writer G.Orwell said: "He who controls the past controls the future. And he who controls the present is omnipotent over the past" 15 . This statement characterized the Soviet era the most accurately, when the intentional distortion of entire periods in the history of Ukraine made it possible to more effectively

\footnotetext{
11 Коннертон П. Соціальна пам'ять // Його ж. Як суспільства пам'ятають / Пер. 3 англ. - К., 2004. - С.36.

12 Там само. - C.40.

13 Там само.

14 Там само. - C.39.

15 Оруэлл Дж. 1984. - Санкт-Петербург, 2003. - 320 с.
} 
sovietize the "liberated" territories and more quickly integrate them into the USSR. In other words, it was possible to control the sovietized Ukrainian lands by introducing an appropriate propaganda mechanism, and the "correct" writing and teaching of history in it should have hold price of place ${ }^{16}$. This is evidenced by hundreds of thousands of records in the collection of party archives, which contain internal memos, reports of propaganda and campaign departments, protocols, provide statistics, names of historian-falsificators, their works, methods of activity.

The Soviet state mechanism atriciously dictated the subjects of research, priority directions, the prism of presentation of events, encouraged faithful executors. This was about the planned propagation of dictate and the levelling of freedom of scientific research from the first years of the Soviet power. Historians were given the task to substantiate the official attitude of the regime to the national, in particular, Ukrainian question. Thus, the key role in further interpreting the "Ukrainian question" was played by materials from 1917-1918, being prepared for the fifth party conference and official appeals from J.Stalin, the People's Commissar for Nationalities, which reveal the content of the state policy in 1920-1930s in the field of the national question ${ }^{17}$. In particular, this refers to the collection of reports, resolutions, and the appeals of J.Stalin "Articles and speeches about Ukraine" (1936), which ambiguously declared the right of "oppressed nations" of the former Russian Empire to self-determination, which, having this right, may not use it, calling it "expediency of separation". Also let's recall the article by J.Stalin "The National Question and Leninism" published in his collected papers on March 18, 1929. It became a confirmation of double standards for this policy.

The first decades of the Soviet dictate radically affected the existence of historical thought, the basis of which is Marxism-Leninism. New branches are formed - the history of the All-Union Communist Party (Bolsheviks) and the history of the Comintern (Communist International) - new key points in the priority of particular problems are highlighted. Gradually, by the end of 1920s, old scientific centers had been ousted, academic institutions had lost the older generation of scientists "inconvenient" for the system. The history of class struggle, which desiccated the presentation of the past, prevails. Historical science becomes an effective tool of propaganda and the formation of class-revolutionary consciousness.

These trends intensified after the appearance of a letter by J.Stalin to the editorial office of the journal "Proletarian Revolution" "On Some Issues in the History of Bolshevism" in 1931. Soon afterwards, the first volumes of "The History of the Civil War in the USSR" were published, and "Comments on the Abstract of the USSR History Textbook" written by J.Stalin, A.Zhdanov and S.Kirov were taken into account when announcing the competition for writing this textbook. In May 1934, a resolution of Sovnarkom of the USSR and the Central Committee of party "On the Teaching of Civil History in Schools of the USSR" was adopted. Soon afterwards, there was the persecution and bashing of scientific historical schools with the further authoritative interference in the interpretation of problems, censorship, unification of textbooks ${ }^{18}$. Compulsory ideological calques, which did not allow a scientist to express his own

\footnotetext{
16 Державний архів Чернівецької області. - Ф.1. - Оп.9. - Спр.2. - 127 арк.; Оп.1. - Спр.184, 204 (об’єднані). - 44 арк.

17 Сталін Й.В. Національне питання і ленінізм // Його ж. Твори: В 11 т. - Т.11. - К., 1949. - С.332-354; Сталин И. Доклад по национальному вопросу на VII (апрельской) конференции РСДРП(б) 1917 г. // Его же. Статьи и речи об Украине: Сборник. - К., 1936. - С.5-11; Совет народных комиссаров об Украине (ноябрь 1917 г.) // Там же. - С.14-17; От народного комиссара по делам национальностей (13 (26) декабря 1917 г.) // Там же. - С.20-26.

18 У лещатах тоталітаризму: перше двадцятиріччя Інституту історії НАН України (1936-1956 рр.): Зб. док. і мат.: У 2 ч. / Упор.: Р.Я.Пиріг (кер. кол.), Т.Т.Гриценко, В.М.Мазур, О.С.Рубльов. - Ч.1 (1936-1944 рр.). - К., 1996. - 146 с.
} 
opinion, to give objective assessments, made historical science only a convenient and effective means of propaganda.

Ideological bias of historians allowed them to distort, write in order to please, believe in it and convince entire communities of it. Here we can mention the well-known documentary work by N. Zemon Davis "The Return of Martin Guerre" as an example of how the collective memory of the inhabitants of the village Artigat, where everyone knew each other so well that the impostor didn't have any trouble to enter their community under another name, allowed him to integrate into the village environment and sail under false colours. Everyone believes in what he wants to believe in, like Martin's wife, B. de Roles, who immediately noticed the impersonation, but wasn't against the community's thought, because the stranger was closer than her real husband.

We can draw a parallel with modern Russia, which inherited and upgraded this mechanism, turned it into a very effective system of manipulation of consciousness, in particular, control of the activities of leading research institutions engaged in the study of history, a selective approach to granting permission for the processing of archival funds, in particular in 1930s - 1940s, the persecution of researchers whose views contradict the generally accepted concept of the past.

The twisted perception of reality is imposed by the ruling power by filling the TV-space with movies on military and pseudo-historical themes, talk shows, serials, in which the "achievements" of the Soviet army are mythologized, odious figures are heroized. Those things that would have been subjected to condemnation once and for all emerge from oblivion again. Even a wave of studies of the totalitarian past of the USSR in Russia has been reduced to a minimum compared with the first "germs" of perestroika. For example, the situation with I.Pavlova, a doctor of historical sciences, a well-known publicist, a former leading research scientist of the Russian Academy of Sciences, the author of the "wrong" conception of the history of Stalinism, looked quite eloquently ${ }^{19}$. After the defence of her thesis turned into a nine-hour harassment in 2002, the scientist had to emigrate to the United States and now lives in Boston. Heavy criticism and vigorous persecution by the Russian scientific community began because of the unbiased approaches to the interpretation of Stalin's time and totalitarism as a phenomenon during perestroika. I.Pavlova communicated with many well-known figures that were prosecuted, repressed, confined in camps, suffered from deportation, worked on archival documents for many years, and, therefore, her research was against the official conception. Studying the current trends in the development of historical science in Russia and the intensification of authoritarian trends, I.Pavlova believes that soon there will be a clear need for a complete review of Soviet history by both Russian and Western historians, but from the standpoint of objectivism. In one of her recent interviews with the Ukrainian edition of The Day, the researcher confirmed the view that historical science in the hands of the power is not only a means of propagating beneficial versions of the past, but also artificial consolidation of power and society around them, stirring up interethnic hatred and, even provoking conflicts, including armed ones. In I.Pavlova's opinion, modern Russia clearly tends towards authoritarianism, because the processes of de-Stalinisation were superficial and more masking by nature, since the very Soviet party nomenclature and its inner circle retained the greatest influence both in Russia and in Ukraine. In fact, there was a resuscitation of the image of a tyrant, which is associated with the "Great Victory", and this mythologema is taken as a basis of the consolidation of society around modern authoritarian power. As the publicist notes, the fate of historians in these processes

19 Гривінський Р. Російська ідентичність: чи є альтернатива великодержавництву-2 // День. - 2015. - 20 серпня. 
is sad - already in the early 1990s, when de-Stalinization somewhat slowed down, informal historians were attacked and persecuted. There was I.Pavlova among them.

A professor of Yale University T.Snyder in the speech "The role of the historian as a whole and in the context of the events we are experiencing" warns about the danger of turning the historian into a temporizer and a propagandist: "Propaganda and exploitation of memory will always exist, history will be able to protect itself, if it remains history, and historians will be able to protect themselves and others only by remaining for ever one". In his opinion, the historian is a constant seeker of truth, but not its owner ${ }^{20}$. Thanks to the facts, he can confirm his own assumptions or formulate new ones, but later new documents, evidences, eyewitnesses will probably appear, therefore everything will change radically.

A professor of University of Leeds J.Harris, the author of two fundamental works devoted to Soviet totalitarianism - "The Anatomy of Terror: Political Violence under Stalin" (2013), "The Great Fear: Stalin's Terror of 1930s" (2016), believes that among the contemporary Russian historians who are investigating 1920-1940s there is a clear trend towards the rehabilitation of Stalinist crimes. He sees the reasons for this in the psychic peculiarities of Russians, the constant infantile dependence on the "firm hand", a paranoid fear, which formed as early as the Middle Ages ${ }^{21}$. The scientist rejects the presence of clinically proven diagnoses of Lenin, Stalin or Putin, instead speaking about "institutional paranoia" and a significant overvaluation of external and internal threats. It should be noted that this constant and total authorities' fear of the "attack" of imaginary enemies seems to be fitted into the thinking of all leaders of Russian Empire, USSR and present-day Russia; it is also inspired by numerous historical studies of the last decades $^{22}$. Western researchers also write about this danger ${ }^{23}$. The statistics of Russians' preferences as of April 2019 seems interesting: 41\% of respondents show respect for J.Stalin, 70\% say that he played a positive role in the history of Russia and they approve of his performance, while only $14 \%$ show negative emotions about him ${ }^{24}$. Thus, such an intellectual situation in historical science devalues the work of the historian himself, since he becomes a tool for ideologizing society, spreading imperial tendencies and discord.

So, we'll try to clearly determine the role of the researcher whose intellectual work would really benefit society. This entails the historian-lawyer who crossexamines a witness in court, extracting from testimonies certain information that is not self-explanatory and may contradict previous statements. "To take something as a testimony, says P.Connerton, means to fix something completely different" 25 .

\footnotetext{
20 «Історик не володіє істиною, він не обов’язково іiі знайде, але він іiі шукає»: інавгураційна промова американського історика Тимоті Снайдера з нагоди початку нового навчального року в Українському католицькому університеті у Львові, 18 вересня 2014 [Електронний pecypc]: https://www.istpravda.com.ua/ articles/2014/09/18/144761/

${ }^{21}$ Harris J. The Great Fear: Stalin's terror of the 1930s. - Oxford, 2013. - 240 p.

22 Чащихин У. Разоблачение клеветы против Сталина и СССР. - Москва, 2017. - 52 с.; Эдельлан О. Сталин, Коба, молодой Сталин в исторических источниках. - Москва, 2016. - 128 с.; Жуков Ю. Народная империя Сталина. - Москва, 2009. - 336 с.; Сюндюков И. Борис Соколов: «В России - снова культ тирана Сталина, который начал ужасную войну и положил 40 миллионов человек» // День. - 2016. - 13 травня.

${ }^{23}$ Rutland P., Shimmield N. Putin's dangerous campaign to rehabilitate Stalin // The Washington Post. - 2019. June 13; Luhn A. Stalin, Russia's New Hero // Ibid. - 2016. - March 11; Beard N. Stalin rises again over Vladimir Putin's Russia, six decades after death // Independent. - 2016. - February 24.

${ }^{24}$ Joseph Stalin: Why so many Russians like the Soviet dictator [Електронний pecypc]: https://www.bbc.com/news/ world-europe-47975704; Боде B. Отношение к Сталину и его эпохе [Електронний pecypc]: https://www.svoboda. org/a/2324708.html; Апулеев И. Всё выше и выше: рейтинг одобрения Сталина побил рекорд [Електронний pecypc]: https:/www.gazeta.ru/politics/2019/04/16_a_12304015.shtml

${ }_{25}$ Коннертон П. Соціальна пам'ять. - С.32-33.
} 
In his opinion, re-enactment does not depend on social memory, because the historian uses sources, archives, memoiristics, fiction. But he can also deal with living witnesses to the pages of the recent past, who are most willing to tell about the experiences, so they will reproduce what is stored in their social memory. However, the obtained information will be checked by him for reliability, otherwise, he as a specialist will lose his independence and authority among fellow historians.

Analyzing the role of the historian in understanding of the past and forming of social memory, P.Connerton notes that it is the historian who, through the practice of reconstruction, using the arsenal of research tools and methods, directly influences the formation of historical memory both in a positive and negative sense. He consideres any attempt to speculate in the past used by the totalitarian regime as "mental enslavement", because in such a way the nation loses its own memory. All this leads to serious deformations of traditional culture and social memory, often these processes, according to the modern Ukrainian researcher O.Stasiuk, are irreversible and may affect future generations ${ }^{26}$.

Thus, writing history is a complex process of creating an image of the past in the collective consciousness of the community, and the mission of the historian is quite contradictory - to form or deform social memory, to promote liberation through the knowledge of truth, or to make entire generations wander about back ways. Only a critical approach allows the researcher of history to be independent from the fleeting circumstances, political situation, ideological stratification, influence of routine of academic norms, authorities. The historian must distance himself from the very source and not trust it blindly, because it can be created by people with their own life priorities. Through the analysis, commenting, deciphering sources, finding arguments, view matching, the historian can make one truly feel, experience, and imagine vision of the past. In respect that the practice of historical research creates a new distance between the present and the past, disengaging people from tradition, historically welltrained memory contrasts with non-reflective traditional memory, then in case of the researcher's ideological bias, we get not a distance but a deep gap.

\section{REFERENCES}

1. Assman, A. (2014). Dlinnaya ten proshlogo: Memorialnaya kultura i istoricheskaya politika. Moskva: Novoe literaturnoe obozrenie. [in Russian].

2. Bakirov, V. (2001). Istorychni formy tsinnisnoi svidomosti. Visnyk Kharkivskoho natsionalnoho universytetu im. V.N. Karazina, (12), 9-15, (13), 9-13. [in Ukrainian].

3. Boiko, 0. (2014). Kolektyvna pamiat: svoieridnist pryrody ta spetsyfika struktury. Khronolohiia radianskoi kultury: konstanty i transformatsii, (3), 8-20. [in Ukrainian].

4. Boiko, 0. (2013). Fenomen sotsialnoi pamiati: osnovni kontseptualni pidkhody do analizu ta interpretatsii. Kultura istorychnoi pamiati: yevropeiskyi ta ukrainskyi dosvid, 35-78. [in Ukrainian].

5. Chashchikhin, U. (2017). Razoblachenie klevety protiv Stalina i SSSR. Moskva. [in Russian].

6. Edelman, 0. (2016). Stalin, Koba, Molodoj Stalin v istoricheskikh istochnikakh. Moskva. [in Russian].

7. Harris, J. (2013). The Anatomy of Terror: Political Violence under Stalin. Oxford: Oxford University Press.

8. Harris, J. (2013). The Great Fear: Stalin's terror of the 1930s. Oxford: Oxford University Press.

9. Kalakura, Ya. (2016). "Syndrom komunikatsii" istorykiv i yoho zhyvuchist u postradianskii ukrainskii istoriohrafii. V.Smolii (Ed.). Istoryk i vlada, 55-77. Kyiv: Instytut istorii Ukrainy NAN Ukrainy. [in Ukrainian].

10. Karlova, V. (2008). Osoblyvosti vidnovlennia istorychnoi pamiati ukrainskoho narodu u konteksti analizu dosvidu postsotsialistychnykh krain. Demokratychne vriaduvannia: naukovyj visnyk, (1), 45-53. [in Ukrainian].

11. Khalbvaks, M. (2005). Kollektivnaya i istoricheskaya pamyat. Neprikosnovennyj zapas: debaty o politike i kulture, 2/3(40/41). [in Russian].

12. Khalbvaks, M. (2007). Sotsialnye ramki pamyati. Moskva: Novoe izdatelstvo. [in Russian].

13. Konnerton, P. (2004). Sotsialna pamiat. P.Konnerton. Yak suspilstva pamiataiut, 21-69. Kyiv: Nika-Tsentr. [in Ukrainian]

14. Marochko, V. (2004). «Torhsyny»: zolota tsina zhyttia ukrainskykh selian. Skhidno-Yevropeiskyi Monitor, 5, 14-15. [in Ukrainian].

${ }^{26}$ Стасюк O.O. Деформація традиційної культури українців в кінці 20-х - на початку 30-х рр. XX ст.: Автореф. дис. ... канд. іст. наук. - К., 2007. - 17 с. 
15. Pozniakova-Kyrbiatieva, E. (2012). Kontseptualizatsiia poniattia i yavyshcha sotsialnoi pamiati. Visnyk Mizhnarodnoho Slovianskoho universytetu, (15, 1-2), 15-21. [in Ukrainian].

16. Starodubtseva, L. (2003). Mnemozina i Leta: Pamyat i zabvenie v istorii kul'tury. Kharkov. [in Russian].

17. Stasiuk, 0.0. (2007). Deformatsiia tradytsiinoi kultury ukraintsiv v kintsi 20-kh - na pochatku 30-kh rokiv XX st.: Extended abstract of Candidate's thesis. Kyiv. [in Ukrainian].

18. Zashkilniak, L. (2006-2007). Istorychna pamiat ta istoriohrafiia yak doslidnytske pole dlia intelektualnoi istorii. Ukraina: kulturna spadshchyna, natsionalna svidomist, derzhavnist, 15, 855-862. [in Ukrainian].

19. Zashkilniak, L. (2016). Nebezpeky istorychnoho myslennia ta sotsialni funktsii istoryka u suchasnomu sviti. V.Smolii (Ed.). Istoryk i vlada, 133-143. Kyiv: Instytut istorii Ukrainy NAN Ukrainy. [in Ukrainian].

20. Zhukov, Yu. (2009). Narodnaya imperiya Stalina. Moskva. [in Russian].

\title{
Марія Мандрик-Мельничук
}

докторка історичних наук, професорка кафедри соціальної медицини та організації охорони здоров'я, Буковинський державний медичний університет (Чернівці, Україна), mandricescudyahoo.com ORCID: http://orcid.org/0000-0001-5995-9003

\author{
Анатолій Коцур \\ доктор історичних наук, \\ професор кафедри етнології та краєзнавства, \\ Київський національний університет ім. Т.Шевченка \\ (Київ, Україна), kotsurapdिeta.ua \\ ORCID: http://orcid.org/0000-0002-7015-8052
}

Тамара Шаравара

докторка історичних наук, професорка, проректорка з науково-педагогічної роботи і перспективного розвитку,

Полтавська державна аграрна академія

(Полтава, Україна), 125125.tshagmail.com ORCID: http://orcid.org/0000-0002-6370-6663

\section{Історична інтерпретація минулого: шлях ментального поневолення чи звільнення?}

\begin{abstract}
Анотація. Мета дослідження полягає у з'ясуванні ролі професійного дослідника в історичній інтерпретації минулого, аналізі ймовірних загроз, які несе у собі спекуляція історичними фактами, подіями, довільне оперування ними, навмисне їх перекручення для формування історичної та соціальної пам'яті. Методологія. Дослідження ґрунтується на принципах історизму, усебічності, об'єктивності, системності. При викладенні матеріалу застосовано загальнонаукові методи аналізу, синтезу, узагальнення, спеціально-історичні (ретроспективний, порівняльний, проблемнохронологічний), а також метод міждисциплінарного та полідисциплінарного синтезу. Наукова новизна. Проаналізовано ролі, які може відігравати фаховий дослідник минулого - від пропаґанди ворожих ідей, вибіркового тлумачення джерел, спекулювання на певній тематиці до неупередженого реконструктора історії, компетентного експерта. Доведено, що замовчування або свідоме спотворення окремих сторінок історії, надмірна їх ідеологізація, що активно практикувалося в радянській науці, прирівнюється до політичного насильства, маніпуляції свідомістю цілих спільнот і поколінь. Застосування таких підходів завжди мало руйнівний характер як для самих дослідників, які виконували невластиві їм ролі, так і для суспільства, котре через незнання власного минулого втрачає візію свого майбутнього. Висновки. Маніпуляції з тлумаченням минулого - різне розуміння одних і тих самих знакових подій, надмірна їх політизація, розкручування образу ворога, навмисне акцентування на людських емоціях, ідеологічні нашарування, пов'язані з тієї чи іншою сторінкою життя народу - мають незворотний вплив на формування соціальної пам'яті. Ці чинники сприяють поглибленню процесів дезінтеґрації суспільства й опосередковано розхитують підвалини державності.
\end{abstract}

Ключові слова: історична пам'ять, соціальна пам'ять, насилля, маніпуляція, історична інтерпретація, історіографія, ментальність. 